\section{経年後のアスベスト含有成形板 の下地調整におけるアスベスト 繊維の飛散性の検証}

\title{
VERIFICATION ON ASBESTOS RELEASE DURING SURFACE PREPARATION OF DETERIORATED ASBESTOS CONTAINING CEMENT SHEETS
}

\author{
林 昭人——1 本橋健司—

古賀純子——3 田村昌隆—— \\ キーワード : \\ アスベスト，成形板，下地調整，塗装下地， \\ アスベスト䋊維の飛散性
}

Keywords:

Asbestos, Cement sheets, Substrate preparation, Substrate for painting, Asbestos fiber release
Akihito HAYASHI $* 1$
Kenji MOTOHASHI- $* 2$ Junko KOGA — $* 3$
Masataka TAMURA $-* 1$

Asbestos cement sheets used under outdoor condition may need surface treatment because of deterioration. Surface preparation of deteriorated asbestos cement sheets may cause asbestos fibers release during surface preparation. However, technical information about fibers release is not enough to design countermeasures for surface preparation of deteriorated asbestos cement sheets at present. In this study, airborne fibrous particles concentration was measured under several ways of surface preparation of existed deteriorated cement sheets containing asbestos, and asbestos fibers in waste water and dust were also analyzed in order to develop safe surface preparation methods for deteriorated asbestos cement sheets.

\section{1. 序}

アスベスト含有建材はすでに製造等が禁止され、また、吹付けア スベスト等については建築物への使用が規制されたことにより、今 後の新設建築物にアスベストが使用されることはない。しかし、既 存建築物においては膨大な量のアスベスト含有建材がストックされ ており、改修工事等における安全性の確認、安全な改修工法の確立 が求められている。

吹付けアスベスト等については一般にアスベスト繊維の飛散の度 合いが大きいと言われることから、平成 18 年の建築基準法の改正に より改修工事の際に除去または封じ込めや囲い込みの措置が規定さ れると共に、その処理の方法が公的仕様書 ${ }^{1)}$ その他で示され、一定 の安全対策が図られている。アスベスト含有成形板については、ア スベスト繊維の飛散の度合いが小さいと一般に言われることから法 的には改修時の除去等の措置は求められていないものの、除去の方 法が公的仕様書 ${ }^{1)}$ で示されている。

一方で、アスベスト含有成形板が外装部に用いられる場合は、経 年による表面塗膜のはく離や摩耗等で美観が低下寸るため等により 塗装改修が必要となる場合がある。塗装改修においては污れや既存 塗膜の除去等の下地調整時に成形板の表面層が傷つきアスベスト繊 維が飛散する恐れがあるものの、アスベスト含有成形板の下地調整 時におけるアスベスト繊維の飛散性に関するデータが少ないため安 全性の確保のための方策は不明であり、標準的改修方法も定まって いない。

本報告では、アスベスト含有成形板の安全な塗装改修方法の基礎 資料を得るため、経年後のアスベスト含有成形板への下地調整を想
定した既存塗膜や污れの除去を行う際の周辺における空気中繊維数 濃度の測定を行うとともに、下地調整により発生する洗浄廃水、ダ スト中のアスベスト繊維の有無の確認を行った。

なお、本報告の一部は、日本建築学会大会において発表済みであ る $^{2)}$ 。

\section{2. 検討の概要}

アスベスト含有成形板の下地調整におけるアスベスト䋊維の飛散 には、下地処理時に飛散する場合と下地処理時に発生した廃水や粉 じん等の回収が不十分で二次的に飛散する場合とが想定される。

本検討では、まず、塗膜の一般的な下地調整方法を参考に、下地 調整方法を、下地調整時の粉じん飛散性の観点及び下地調整時の廃 水やダスト発生の観点から、複数種類について実施できるよう設定 した。これらの下地調整方法を既存の建築物の屋根及び外壁に使用 されたアスベスト含有成形板、屋外で長期間ばくろされたアスベス 卜含有成形板の試験体について適用し、作業環境及び周辺環境にお いて空気中繊維数濃度の測定を行った。さらに、その際に発生する 洗浄廃水、ダスト中のアスベスト繊維の有無および含有量の確認を 行った。

なお、経年後の成形板の下地調整時におけるアスベスト繊維の飛 散性には、成形板表層の劣化状沉が影響すると推定される。このた め、本検討においては、既往の検討 ${ }^{3}$ により提案された表 1 に示寸 アスベスト含有成形板の表面劣化度判定手法を用い、表層の劣化状 態の確認を行うこととした。

\footnotetext{
*1 独建築研究所材料研究グループ 交流研究員

（干 305-0817 つくば市立原 1)

芝浦工業大学教授, 独建築研究所 客員研究員 - 博士 (工学)

独建築研究所材料研究グループ 主任研究員・博士 (工学)

Cooperative Researcher, Dept. of Building Materials and Components, Building Research Institute

Prof., Shibaura Institute of Technology, Dr. Eng.

*3 Senior Researcher, Dept. of Building Materials and Components, Building Research Institute, Dr. Eng.
} 
表 1 アスベスト含有成形板の表面劣化度の区分案 ${ }^{3}$

\begin{tabular}{|c|c|c|c|}
\hline 劣化度 & 塗膜の状態 & アスベスト繊維の状態 & $\begin{array}{c}\text { 電顕写真または } \\
\text { 分散染色法 } \\
\end{array}$ \\
\hline I & $\begin{array}{l}\text { 表面が塗膜で } \\
\text { 覆われている }\end{array}$ & - & $\begin{array}{l}\text { アスベスト繊維 } \\
\text { は認められない }\end{array}$ \\
\hline II & $\begin{array}{l}\text { 塗膜の一部に } \\
\text { 剥れ等が認め } \\
\text { られる } \\
\end{array}$ & $\begin{array}{l}\text { 表面はセメントに覆われ } \\
\text { ていてアスベスト繊維は } \\
\text { 認められない }\end{array}$ & $\begin{array}{l}\text { アスベスト繊維 } \\
\text { は認められない }\end{array}$ \\
\hline III & $\begin{array}{l}\text { 塗膜の剥れが } \\
\text { 目立つ }\end{array}$ & $\begin{array}{l}\text { 表面劣化が認められアス } \\
\text { ベスト繊維の露出が部分 } \\
\text { 的に認められる } \\
\end{array}$ & $\begin{array}{l}\text { アスベスト瀻維 } \\
\text { が部分的に認め } \\
\text { られる } \\
\end{array}$ \\
\hline IV & $\begin{array}{l}\text { 塗膜が認めら } \\
\text { れない }\end{array}$ & $\begin{array}{l}\text { 表面層のアスベスト繊維 } \\
\text { が露出している }\end{array}$ & $\begin{array}{l}\text { アスベスト繊維 } \\
\text { の付着が認めら } \\
\text { れる } \\
\end{array}$ \\
\hline
\end{tabular}

\section{3. 下地調整方法の検討}

下地調整の方法は、公的仕様書 1)の “塗り仕上げ外壁等の改修” に示される工法を参考に検討を行った。公的仕様書 1)では、“既存塗 膜等の除去及び下地処理工法” として、サンダー工法、高圧水洗工 法、塗膜はく離剂工法、水洗い工法が記されている。これらの工法 のうち、高圧水洗工法、水洗い工法等を参考にして、高圧水洗、シ ユロぼうきによる方法を設定した（表 2 )。

\section{表 2 本検討で設定する下地調整工法}

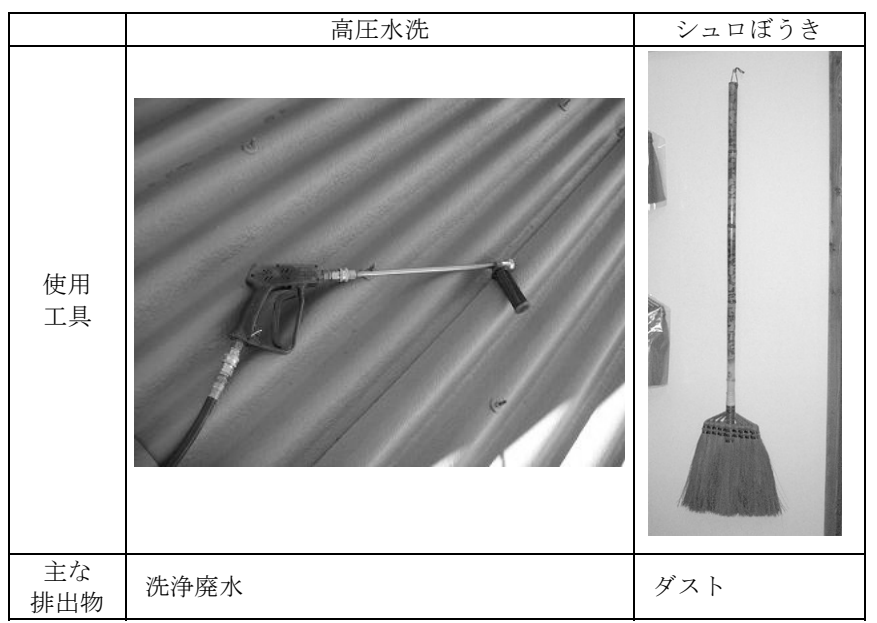

高圧水洗による下地調整は、高圧水の吐出圧力を約 $10 \mathrm{MPa}$ 、下地 調整面との距離を $30 \mathrm{~cm}$ 程度とした。高圧水の吐出圧力は、通常の工 事ではさらに高圧で行われることが多いが、高圧になるほど廃水量 が多く処理が困難になると考えられることから、本検討では約 10MPa とした。本下地調整方法では、下地調整面が湿潤状態になる ためアスベスト繊維の空気中の飛散を一定程度抑制可能な方法と想 定して設定した。

シュロぼうきによる下地調整は、湿潤させない状態で物理的な力 を加え表面の付着物を除去する方法として設定した。通常の工事で はシュロぼうきを用いることは少なくデッキブラシ等を用いること が想定されるが、下地調整面を傷付けず付着物等のみを適度に除去 しアスベスト繊維をなるべく飛散させないことを企図し選定した。 また、あらかじめ表面を水洗し、付着物を一定程度除去すると共に、 下地調整面を湿潤化することでアスベスト繊維の飛散を抑制する方 法も考えられるものの、屋根面に適用した場合は足元がすべりやす く作業時に危険を伴うため、実施しないこととした。

\section{4. 経年後のアスベスト含有成形板に対する下地調整時の空気中繊} 維数濃度の測定

\section{1 概要}

本章では、2010 年 1 月に実施した既存建築物の外壁・屋根壁面を 対象とした下地調整実験、及び 2010 年 $10 \sim 11$ 月に実施した屋外ば くろ試験に供された試験体を対象とした下地調整実験を実施した際 の空気中繊維数濃度の測定について概要を述べる。

\section{2 既存建築物の外壁·屋根面における下地調整時の空気中繊維数 濃度の測定 \\ 1) 測定対象及び下地調整の概要}

測定対象とした建築物は、茨城県古河市に位置する築 23 年の工場 倉庫である。外観を図 1 に示寸。

調査を実施し た箇所は 2 階建 て部分の屋根お よび屋根の東側 に位置する外壁 面である。外壁 面及び屋根面に は、作業及び調 查時の安全確保

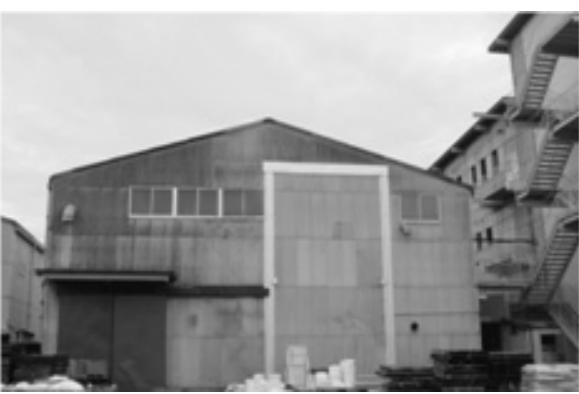

図 1 対象建築物の外観
のため、足場及び命綱を各々設置した。

実験に供する成形板は、屋根面のスレート大波板及び外壁面のス レート小波板である。成形板の概要を表 3 に示寸。アスベスト含有 率は JIS A 1481:2008（建材製品中のアスベスト含有率測定方法） 4) に基づき実施し、（社）日本作業環境測定協会の石綿分析技術の評 価事業(建材製品中の石綿含有率測定に関するクロスチェック事業) においてAランクと認定された分析技術者が行った。成形板の表面 劣化度は表 1 の区分案に基づき判断を行った。

下地調整は、屋根は高圧水洗及びシュロぼうきにより実施し、外 壁は垂直面でありシュロぼうきでの下地調整は現実的でないことか ら高圧水洗のみとした。

表 3 成形板の概要及び下地調整

\begin{tabular}{|l|l|l|}
\hline 成形板 & 外壁（スレート小波板） & 屋根（スレート大波板） \\
\hline & & \\
外観
\end{tabular}

2) 空気中繊維数濃度の測定

空気中繊維数濃度の測定は、下地調整実施箇所の周囲および対象 建築物の周囲各 4 力所とした。外壁面については、敷地境界（塀が 設置されている）との間隔が狭いこと、外壁面にそって作業足場を 設置したことから、足場内の中央と足場の北端、南端の 3 力所とし 
た。測定箇所を図 2 に示す。測定は、下地調整実施前、実施中、終 了後とした。この他に、下地調整実施中に作業者の呼吸域（個人ば く露濃度）において䋊維濃度の測定を行った。サンプリング条件を 表 4 に示す。

空気中繊維数濃度の分析方法は以下とする。

- 分析方法 : JIS K 3850-1:2006 (空気中の繊維状粒子測定方法） ${ }^{5)}$

- 分析技術者：(社) 日本作業環境測定協会の石綿分析技術の評価事 業における空気中の石綿計数分析に関するクロスチェックでA ンクと認定された分析技術者

・測定繊維 :「総緎維数濃度」「無機質繊維数濃度」および「アス心゙ スト繊維数濃度」の 3 種類、ただし「無機質繊維数濃度」、「アス ベスト繊維数濃度」はそれぞれ「総䋊維数濃度」、「無機質䋊維数 濃度」の結果が定量下限以下であった場合は実施しない

\section{3) 測定結果}

下地調整及び測定は、2010 年 1 月 25 日〜27 日に実施され、天候 はいずれの実施日も晴れであった。また、実施前 1 週間以内は降雨 が無く、実験を実施した成形板は乾燥した状態にあった。

下地調整は、表面の付着物等が概ね除去されたことを確認するま で行った。下地調整に要した時間及びサンプリング時間を表 5 に示 す。この他に、作業者の呼吸域において 10 分間、下地調整実施前に 30 分間、下地調整実施後 30 分後から 30 分間のサンプリングを行っ た。

表 6 に測定した下地調整実施中の空気中繊維数濃度の結果を示す。 下地調整実施前、下地調整実施 30 分後からの空気中繊維数濃度につ いては、総䋊維数濃度がいずれも定量下限未満で、無機質繊維数濃 度、アスベスト繊維数濃度については分析を実施しなかったため、
表では省略した。

下地調整実施前の空気中繊維数濃度においては、いずれも総繊維 数濃度が定量下限未満であり、アスベス卜繊維は検出されなかった。 経年による成形板表面の劣化により、周辺空気中にアスベス卜繊維 の飛散する場合が想定されたが、本測定の範囲ではアスベスト緎維 の飛散は認められなかった。

一方、下地調整中の空気中繊維数濃度について、総繊維、無機質 繊維が検出された場合があるものの、アスベスト繊維はいずれの場 合も定量下限未満で空気中への飛散は認められなかった。ここで、 無機質繊維数濃度が総繊維数濃度を上回っている場合があるが、屋 根、外壁ともにほこりや苔などの付着物がある状態での下地調整で あたったため、メンブレンフィルターにこれらの夾雑物が付着し、 計数に影響したこと等が考えられる。下地調整時のアスベスト含有 成形板からのアスベスト繊維の飛散性は成形板の表面劣化度、下地 調整の方法により異なると想定されたが、本検討の範囲ではアスベ

表 4 サンプリング条件

\begin{tabular}{|l|c|c|c|}
\hline & a. 建築物周囲 & b. 建材周囲 & c. 作業者呼吸域 \\
\hline 吸引流量 & $10 \mathrm{~L} / \mathrm{min}$ & $5 \mathrm{~L} / \mathrm{min}$ & $1 \mathrm{~L} / \mathrm{min}$ \\
\hline $\begin{array}{l}\text { メンブレンフ } \\
\text { イルター }\end{array}$ & フイルター径 $47 \mathrm{~mm}$ & フィルター径 $25 \mathrm{~mm}$ & フ似一径 $25 \mathrm{~mm}$ \\
平均孔径 $0.8 \mu \mathrm{m}$ & 平均孔径 $0.8 \mu \mathrm{m}$ & 平均孔径 $0.8 \mu \mathrm{m}$ \\
\hline 有効直径 & $35 \mathrm{~mm}$ & $22 \mathrm{~mm}$ & $22 \mathrm{~mm}$ \\
\hline
\end{tabular}

表 5 下地調整に要した時間及びサンプリング時間

\begin{tabular}{|c|c|c|c|c|}
\hline \multirow{2}{*}{ 成形板 } & \multirow{2}{*}{$\begin{array}{c}\text { 下地調整 } \\
\text { 時間 }\end{array}$} & \multicolumn{2}{|c|}{ サンプリング時間 } & \multirow{2}{*}{ 風向風速 } \\
\hline & & a. 建築物 & b. 建材 & \\
\hline $\begin{array}{l}\text { 外壁（スレート小波 } \\
\text { 板）: 高圧水洗 }\end{array}$ & 30 分 & 30 分 & 30 分 & $\begin{array}{l}\text { 南または北風 } \\
0.70 \sim 0.80 \mathrm{~m} / \mathrm{s}\end{array}$ \\
\hline $\begin{array}{l}\text { 屋根（スレート大波 } \\
\text { 板）: 高圧水洗 }\end{array}$ & 74 分 & 88 分 & 74 分 & $\begin{array}{c}\text { 西風 } 0.15 \sim \\
0.65 \mathrm{~m} / \mathrm{s}\end{array}$ \\
\hline $\begin{array}{l}\text { 屋根（スレート大波 } \\
\text { 板）：シュロぼうき }\end{array}$ & 50 分 & 62 分 & 50 分 & $\begin{array}{c}\text { 西風 } 1.45 \sim \\
1.70 \mathrm{~m} / \mathrm{s}\end{array}$ \\
\hline
\end{tabular}

表 6 下地調整中の空気中繊維数濃度

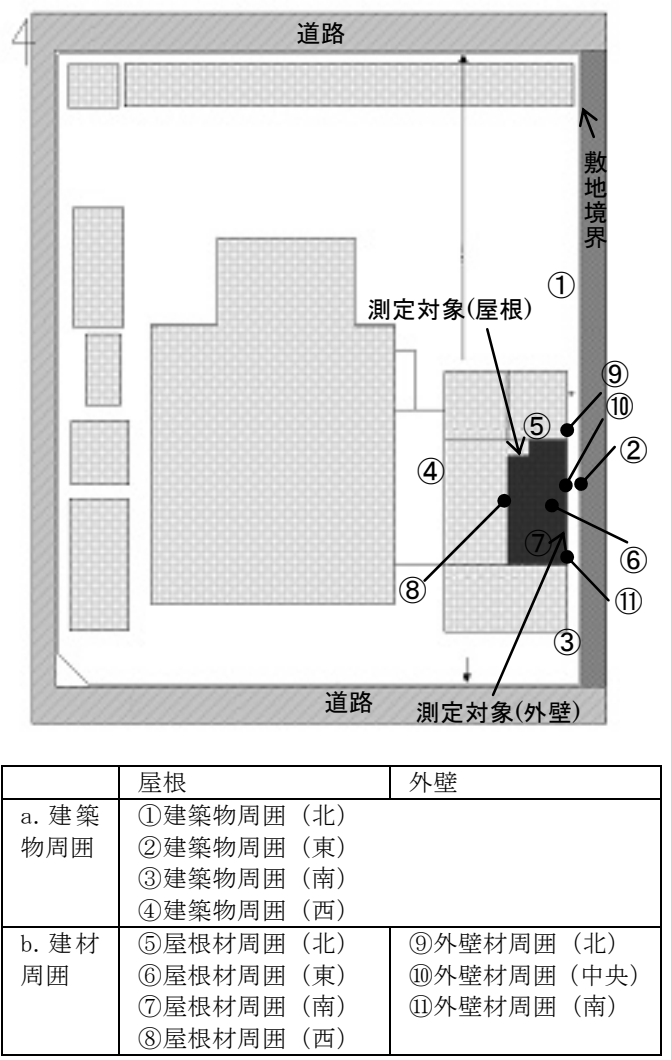

\begin{tabular}{|c|c|c|c|c|c|}
\hline $\begin{array}{l}\text { 実施箇所 } \\
\text { • 下地調整 }\end{array}$ & 採取場所 & $\begin{array}{l}\text { 総緎維数 } \\
\text { 濃度 }(\mathrm{f} / \mathrm{L})\end{array}$ & $\begin{array}{l}\text { 無機質繊維 } \\
\text { 数濃度 }(\mathrm{f} / \mathrm{L})\end{array}$ & $\begin{array}{l}\text { アスベス卜緎維 } \\
\text { 数濃度 }(\mathrm{f} / \mathrm{L})\end{array}$ & $\begin{array}{c}\text { 定量下限 } \\
\text { (f/L) }\end{array}$ \\
\hline \multirow{9}{*}{$\begin{array}{c}\text { 外壁 } \\
\text { - 高圧水洗 }\end{array}$} & (1)建築物周囲（北） & 3.6 & 9.9 & $\langle 2.4$ & \multirow{4}{*}{2.4} \\
\hline & (2)建築物周囲（東） & 6.3 & $<2.4$ & - & \\
\hline & (3)建築物周囲（南） & $<2.4$ & - & - & \\
\hline & (4)建築物周囲（西） & $<2.4$ & - & - & \\
\hline & (9)外壁材周囲（北） & 34 & 45 & $<1.9$ & \multirow{3}{*}{1.9} \\
\hline & (10)外壁材周囲 (中央) & 2.1 & 6.4 & $<1.9$ & \\
\hline & (11)外壁材周囲（南） & 5.7 & 12 & $<1.9$ & \\
\hline & 呼吸域（作業者 A） & 42 & 390 & $<28$ & \multirow{2}{*}{28} \\
\hline & 呼吸域（作業者 B） & 42 & 130 & $<28$ & \\
\hline \multirow{9}{*}{$\begin{array}{c}\text { 屋根 } \\
\text { ·高圧水洗 }\end{array}$} & (1)建築物周囲（北） & 1.4 & $<0.9$ & - & \multirow{4}{*}{0.9} \\
\hline & (2)建築物周囲（東） & 1.9 & $<0.9$ & - & \\
\hline & (3)建築物周囲（南） & $<0.9$ & - & - & \\
\hline & (4)建築物周囲（西） & $<0.9$ & - & - & \\
\hline & (5)屋根材周囲（北） & 2.7 & 3.9 & $<0.8$ & 0.8 \\
\hline & (6)屋根材周囲（東） & 3.4 & 3.7 & $<0.9$ & 0.9 \\
\hline & (7)屋根材周囲（南） & 8.0 & 8.9 & $<0.9$ & 0.8 \\
\hline & 8屋根材周囲（西） & 3.0 & 6.1 & $<0.9$ & 0.9 \\
\hline & 呼吸域（作業者 A） & 32 & $<28$ & - & 28 \\
\hline \multirow{9}{*}{$\begin{array}{c}\text { 屋根・シュロ } \\
\text { ぼうき }\end{array}$} & (1)建築物周囲（北） & $<1.3$ & - & - & 1.3 \\
\hline & (2)建築物周囲（東） & $<1.2$ & - & - & 1.2 \\
\hline & (3)建築物周囲（南） & $<1.2$ & - & - & 1.2 \\
\hline & (4)建築物周囲（西） & $<1.1$ & - & - & 1.1 \\
\hline & (5)屋根材周囲（北） & 2.1 & 8.4 & $\langle 1.2$ & \multirow{4}{*}{ 1. 2} \\
\hline & (6)屋根材周囲（東） & 8.5 & 2.2 & $<1.2$ & \\
\hline & (7)屋根材周囲（南） & 6.4 & 6.8 & $<1.2$ & \\
\hline & 8屋根材周囲（西） & 9.2 & 8.0 & $<1.2$ & \\
\hline & 呼吸域（作業者 A） & 53 & 32 & $<28$ & 28 \\
\hline
\end{tabular}


ス卜䋊維の飛散は確認できなかった。また、下地調整実施 30 分後以 降については、総繊維数濃度が定量下限未満となり、粉じんの飛散 は収まっている状態であること、アスベスト繊維は検出されないこ とが確認された。

\section{3 屋外ばくろに供した試験体の下地調整時の空気中繊維数濃度 の測定}

\section{1) 測定対象及び下地調整の概要}

測定対象とした試験体は、独立行政法人建築研究所の屋外ばくろ 場で屋根を想定し傾斜を設けてばくろされた成形板である。

成形板の概要を表7に示す。アスベスト含有率は 4.2 と同様に分 析を行った結果を、劣化度は表 1 の区分案に基づき判断した結果を 示した。いずれもばくろ試験開始から約 30 年経過している。4.2の 実験で空気中へのアスベスト䋊維の飛散が確認されなかったことか ら、アスベスト繊維がより飛散しやすいことが想定される、より表 面劣化度が高い成形板に対してシュロぼうきでの下地調整を行うこ ととした。

また、アスベスト繊維の飛散が予想されるため、実験は単管パイ プで組んだ枠をビニルシートで覆い、負圧除じん装置により内部を 負圧とした仮設チャンバー内で実施し、アスベスト繊維が周囲に飛 散しないよう配慮した。

\section{2) 空気中繊維数濃度の測定}

空気中繊維数濃度の測定は、図 3 に示寸仮設のチャンバー内部で 行うこととした。下地調整は図 3 中に示す位置に大型の扇風機 2 台 を設置し送風を行い実施した。測定箇所は図 3 中に示寸ように扇風 機からの送風の試験体の風下の位置及び作業者の呼吸域（個人ばく 露濃度）とした。測定条件を及びサンプリング時間を表８に示寸。 また、サンプリング条件を表 9 に示す。

\section{3)測定結果}

下地調整及び測定は、2010 年 10 月 27 日〜 11 月 4 日に実施され、 天候は晴れまたは量りであった。試験片は実験開始前 1 週間以上に

\begin{tabular}{|l|l|l|}
\multicolumn{3}{c}{ 表 7 成形板の概要及び下地調整 } \\
\hline No. & 1 & 2 \\
\hline 形板 & スレート小波板 & 住宅屋根用化粧スレート \\
\hline & & \\
\hline
\end{tabular}

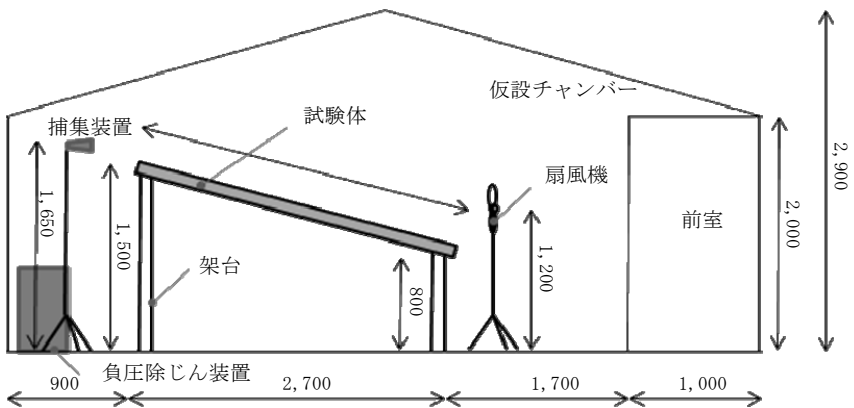

i ）側面図（試験体№.1）

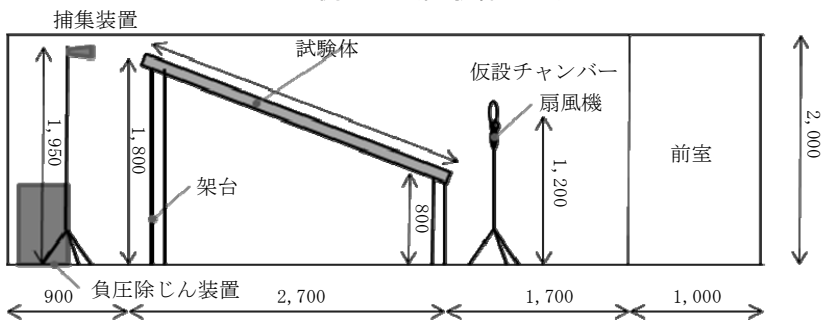

ii ）側面図（試験体№. 2)

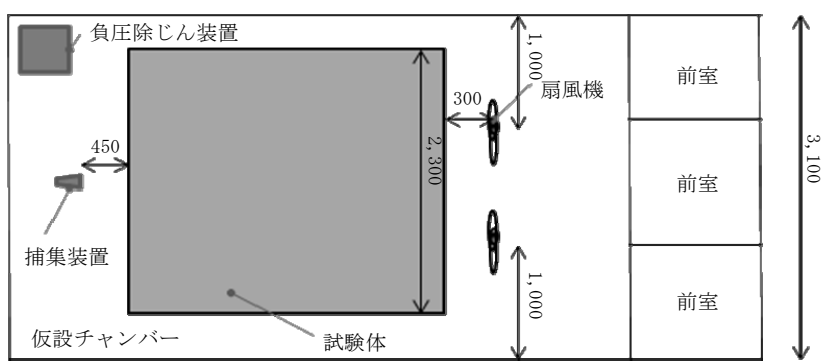

iii）平面図（試験体N No. 1、2 共通）

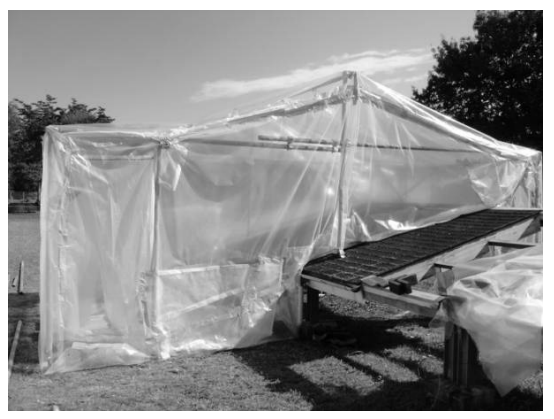

iv）設置状況

図 3 仮設チャンバーの概要（単位：mm）

表 8 測定条件
\begin{tabular}{|l|l|l|}
\hline & 測定条件 & サンプリング時間 \\
\hline ア & 下地調整前、無風 & 240 分 \\
\hline イ & 下地調整前、送風 & 240 分 \\
\hline ウ & 下地調整実施中、送風 & 15 分 (No. 1) \\
& 分 (No. 2) \\
\hline エ & 下地調整実施中及び実施後、送風 & 240 分 \\
\hline オ & 下地調整実施中の作業者呼吸域 & 10 分 \\
\hline
\end{tabular}

\begin{tabular}{|c|c|c|}
\hline & 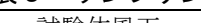 & \\
\hline 吸汇流昌 & 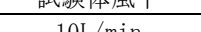 & $1 / \mathrm{min}$ \\
\hline $\begin{array}{l}\text { メンブレンフ } \\
\text { イルター }\end{array}$ & $\begin{array}{c}\text { フ似一径 } 47 \mathrm{~mm} \\
\text { 平均孔径 } 0.8 \mu \mathrm{m}\end{array}$ & $\begin{array}{c}\text { フィル夕一径 } 25 \mathrm{~mm} \\
\text { 平均孔径 } 0.8 \mu \mathrm{m}\end{array}$ \\
\hline 有効直径 & $35 \mathrm{~mm}$ & $22 \mathrm{~mm}$ \\
\hline
\end{tabular}


わたり、ビニルシート又は仮設チャンバーで覆い、乾燥した状態で 実験を行った。

下地調整は、表面の付着物等が概ね除去されたことを確認するま で行った。下地調整に要した時間帯は、№. 1 で 15 分、№. 2 で 10 分 間であった。なお、各仮設チャンバー内部の風速及び測定位置を図 4 に示す。

分析結果を表 10 に示す。総繊維数濃 度・無機質繊維数濃 度としては検出され たが、アスベスト繊 維数濃度は定量下限 未満であった。飛散 している繊維のほと んどがアスベスト繊 維では無いという結 果となった。

ここで、下地調整 により発生し回収さ れたダストを目視で 観察したところ、経 年に伴う劣化で脆く なった試験体の表面 層が除去され排出し ていることが確認さ れた。アスベスト繊 維もアスベスト含 有成形板から離脱

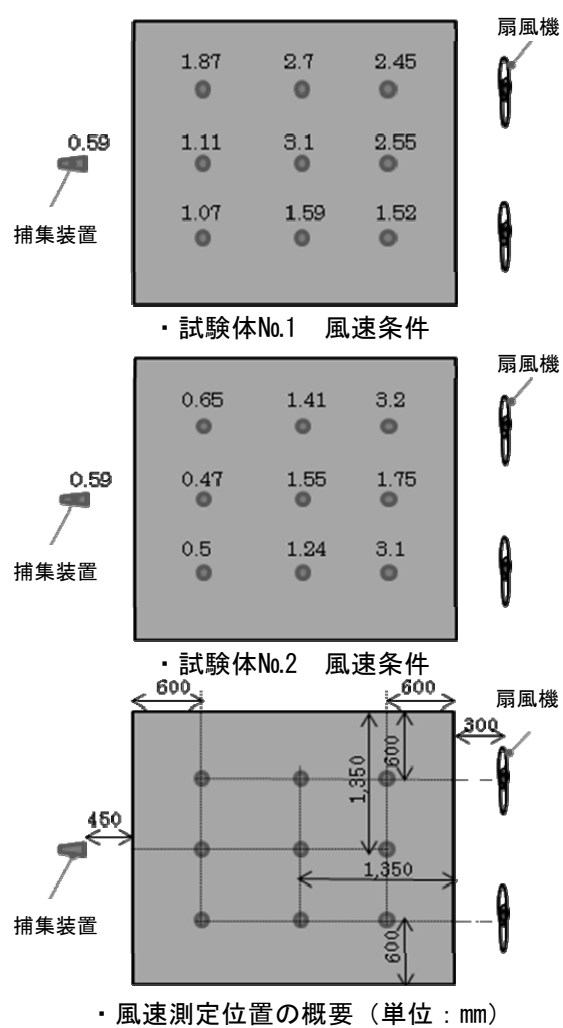

図 4 送風時の風速条件及び測定位置の概要
しダスト中に混入していることが想定される。これらの繊維は、成 形板のセメント分が付着したために空気中に飛散しなかった、ある いは飛散し捕集装置で捕集されても検出されなかったことが考えら れる。

JIS K 3850-1:2006 空気中の繊維状粒子測定方法 ${ }^{5}$ においては、 繊維状粒子の数の判定方法として、“繊維がからまって正確に数を読 みとることができない場合には、数えない”、“粒子が付着している 繊維状粒子の場合には、粒子の幅が $3 \mu \mathrm{m}$ を超えるものは数えない” ことが規定されている。アスベスト含有成形板から飛散したアスベ スト繊維にセメント分が付着し、またはセメント分の付着によりア スベスト繊維が束状になっている場合には計数されないことが想定 される。

表 10 空気中繊維数濃度分析結果

\begin{tabular}{|c|c|c|c|c|c|c|}
\hline $\begin{array}{l}\text { 成 } \\
\text { 形 } \\
\text { 板 }\end{array}$ & $\begin{array}{l}\text { 測定 } \\
\text { 条件 }\end{array}$ & $\begin{array}{l}\text { 総繊維 } \\
\text { 数濃度 } \\
(\mathrm{f} / \mathrm{L})\end{array}$ & $\begin{array}{c}\text { 無機質繊 } \\
\text { 維数港度 } \\
\text { (f/L) }\end{array}$ & $\begin{array}{c}\text { 夘多仪綫 } \\
\text { 維数濃度 } \\
(\mathrm{f} / \mathrm{L})\end{array}$ & $\begin{array}{l}\text { クロシドライト } \\
\text { 緎維数濃 } \\
\text { 度 }(\mathrm{f} / \mathrm{L})\end{array}$ & 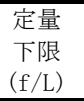 \\
\hline \multirow{5}{*}{1} & $\bar{P}$ & 0.3 & $<0.3$ & - & - & 0.3 \\
\hline & 1 & $<0.3$ & - & - & - & 0.3 \\
\hline & ウ & 170 & 160 & $<5$ & $<5$ & 5 \\
\hline & $I$ & 15 & 15 & $<0.6$ & $<0.6$ & 0.3 \\
\hline & オ & 840 & 190 & $<30$ & - & 30 \\
\hline \multirow{5}{*}{2} & $P$ & $<0.3$ & - & - & & 0.3 \\
\hline & 1 & 0.3 & $<0.3$ & - & & 0.3 \\
\hline & ウ & 130 & 63 & $<8$ & & 8 \\
\hline & I & 11 & 5.4 & $<0.6$ & & 0.6 \\
\hline & 才 & \multicolumn{5}{|c|}{ （フィルター装着の不備により 分析できず） } \\
\hline
\end{tabular}

このように JIS 法 ${ }^{4)}$ では検出されないアスベスト繊維が捕集されて いるか否かを確認するため、JIS 法の分析前に以下の工程を追加し た方法でも実施することとした（以降、“分散後”と表記）。

・メンブレンフィルターの一部（JIS 法による分析の残余部分）を 一定量の無じん水中に入れ、超音波により分散

・十分な分散の後に適量について新たなメンブレンフィルターにて 万過

なお、測定条件のアではアスベスト繊維の飛散が少ないことが予想 されるため実施しなかった。

分析結果を表 11 に示す。分散工程を追加した場合においても、空 気中からはアスベスト繊維は検出されなかった。このため、本実験 の下地調整により成形板から離脱したアスベスト繊維は空気中への 飛散は非常に少なかったことが推量される。一方で、ダストとして アスベスト䋊維が排出されている可能性が高いことから、適切な処 理を行うよう配慮する必要がある。

表 11 分散工程を加えた場合の空気中繊維数濃度分析結果

\begin{tabular}{|c|c|c|c|c|c|c|}
\hline $\begin{array}{l}\text { 成 } \\
\text { 形 } \\
\text { 板 }\end{array}$ & $\begin{array}{l}\text { 測定 } \\
\text { 条件 }\end{array}$ & $\begin{array}{l}\text { 総繊維 } \\
\text { 数濃度 } \\
(\mathrm{f} / \mathrm{L})\end{array}$ & $\begin{array}{c}\text { 無機質繊 } \\
\text { 維数濃度 } \\
\text { (f/L) }\end{array}$ & $\begin{array}{c}\text { クリリタイル繊 } \\
\text { 維数濃度 } \\
(\mathrm{f} / \mathrm{L})\end{array}$ & $\begin{array}{c}\text { クロシドライト繊 } \\
\text { 維数滣度 } \\
\text { (f/L) }\end{array}$ & $\begin{array}{l}\text { 定量 } \\
\text { 下限 } \\
(\mathrm{f} / \mathrm{L})\end{array}$ \\
\hline \multirow{5}{*}{1} & $\bar{P}$ & \multicolumn{5}{|c|}{ (実施せず) } \\
\hline & $\begin{array}{c} \\
\end{array}$ & 5.4 & $\langle 1.2$ & - & - & 1.2 \\
\hline & ウ & 1100 & 1000 & $\langle 20$ & $<20$ & 20 \\
\hline & I & 180 & 170 & $\langle 2.4$ & $\langle 2.4$ & 2.4 \\
\hline & 才 & 1800 & 290 & $\langle 120$ & $\langle 120$ & 120 \\
\hline \multirow{5}{*}{2} & P & \multicolumn{3}{|c|}{ (実施せず) } & & (実施せず) \\
\hline & T & 18 & $\langle 1.2$ & - & & 1.2 \\
\hline & ウ & 1500 & 110 & $\langle 32$ & & 32 \\
\hline & I & 50 & 11 & $\langle 2.4$ & & 2.4 \\
\hline & 才 & \multicolumn{5}{|c|}{ (メンブレンフィルター装着の不備により分析できず) } \\
\hline
\end{tabular}

5. 下地調整により発生する洗浄廃水及びダストの検証

\section{1 検証方法}

本章では、4。で下地調整を行った実験時に排出した高圧洗浄廃 水中のアスベストの有無及びダスト中のアスベストの有無、程度を 確認する。

水中のアスベスト繊維については、アスベストを含有する水道管 が用いられた場合の水道水中のアスベストを分析する方法として定 められた分析手法 ${ }^{6)}$ などがある。ここでは、洗浄廃水中の有無につ いて確認することが目的であるため、JIS A 1481:2008 れた X 線回折法による定性分析を準用し、洗浄廃水を直径 $25 \mathrm{~mm}$ ふっ 素樹脂バインダグラスフィルターにてろ過した後、水分を蒸発させ た固形分についてアスベストの混入の有無を確認することとした。

ダスト中のアスベストについては、同様に JIS A 1481:2008) で 定められた方法により定量分析を行うこととした。

\section{2 既存建築物の外壁・屋根面における下地調整時に発生した高圧 洗浄廃水及びダストの検証}

4.2 で述べた既存建築物の外壁・屋根面の下地調整を行った際に 排出された外壁面の高圧洗浄廃水及び屋根面の高圧洗浄廃水に含ま れる固形分、並びにシュロぼうきでの清掃時に発生したダストを対 象とし、X 線回折法によりアスベスト繊維の有無について分析を行 った。

屋根面の高圧洗浄廃水は、既存の雨樋の端部に容器を設置し、外 壁面の高圧洗浄廃水は、外壁の下部に容器を設置し各々回収した。 回収状況を図 5 に示す。ダス卜は、下地調整時に発生箇所にて周囲 
に飛散しないようその都度回収した。

図 6 に、X 線回折法により高圧洗浄廃水中固形分の分析を行った 結果を示す。外壁、屋根のいずれの洗浄廃水の分析結果においても、 回折ピークからクリソタイル $\left(\mathrm{Cu}-\mathrm{k} \alpha\right.$ 線、2 $\theta: 12.1^{\circ}, 24.3^{\circ}$, $\left.19.4^{\circ}\right)$ を含有していることが確認できた。また、位相差・分散顕 微鏡による分析でもクリソタイルが確認され、成形板に含有するア スベストの種類と一致したことから、下地調整により廃水中にアス ベストが排出されたと考えられる。

また、表 12 にダスト中のアスベスト含有率の分析結果を示す。ダ スト中には下地調整によりアスベスト含有成形板から離脱したアス ベストが含まれていることが確認された。

\section{3 屋外ばくろに供した試験体の下地調整時に発生したダストの 検証}

4.3 で述べた屋外ばくろ試験体に供されたアスベスト含有成形板 に下地調整を行った際に発生したダストを回収し、X 線回折法でア スベストの有無について分析を行った。分析結果を表 13 に示す。い ずれの試験体のダストからもアスベストが確認された。

\section{4 考察}

アスベスト含有成形板の下地調整により発生した洗浄廃水、ダス トにはアスベストが含有していることが確認された。

ダスト中のアスベストは本実験の結果からはダストに対し質量比 で $2.3 \%$ ～ $5.8 \%$ という結果であり、建材に含有する量を鑑みると少 なくない量が含まれていることが確認された。

廃水中のアスベストについては、定性分析のみを実施したため含 有の程度は不明であるものの、シュロぼうきによる下地調整と同等 の量が発生している可能性がある。

空気中に飛散したアスベスト繊維については、4，の空気中繊維 数濃度の確認により、空気中への飛散が定量下限未満であったこと から、少なくとも下地調整時には作業者等への健康被害の危険性は 小さい。しかし、高圧洗浄廃水やダス卜を放置した場合に二次的な 飛散が発生する危険性については、現時点では不明である。これら について回収し、適切な処理を行う必要がある。

\section{6. 結}

経年変化したアスベスト含有成形板に下地調整を実施した際の空 気中䋊維数濃度及び下地調整に伴い発生する廃水、ダスト中のアス ベストの検証を行った。

下地調整時の周辺空気中へのアスベスト繊維の飛散の程度は、成 形板の劣化程度、下地調整の方法により異なると推量されるものの、 本検討で検討した表面の劣化が相当程度進行したアスベスト含有成 形板の下地調整においては、空気中へのアスベスト繊維の飛散は確 認されなかった。本検討においては、アスベスト繊維を飛散させな いことに配慮した方法を下地調整方法として設定しており、少なく とも、本実験の方法による下地調整においては一定の安全性を確認 することができた。ただし、下地調整に伴い発生する廃水、ダス卜 にはアスベストが混入しており、これらの排出物については適切な 回収・処理が必要である。

また、下地調整の程度は、塗膜の付着性に影響する。塗装改修に おいては、アスベスト含有成形板の下地調整方法に対し、アスベス 卜繊維の飛散性のみならず、下地調整面の評価を行う必要がある。
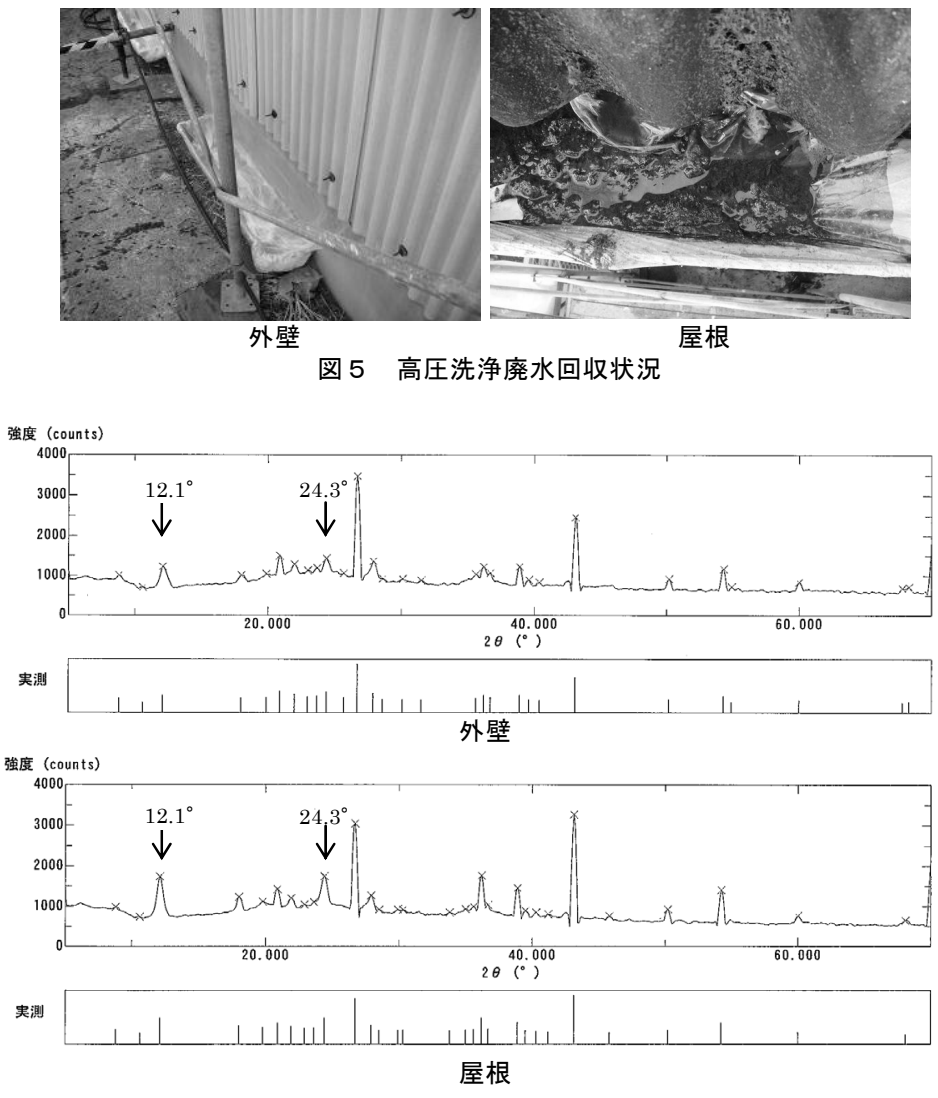

図 6 X 線回折法による高圧洗浄廃水中固形分の分析結果

表 12 既存建築物の外壁・屋根面における 下地調整時に発生したダスト中のアスベスト含有率

\begin{tabular}{|l|l|l|}
\hline & $\begin{array}{l}\text { ダスト中のアス } \\
\text { ベスト }\end{array}$ & $\begin{array}{c}\text { 参考) 成形板中の } \\
\text { アズトト }\end{array}$ \\
\hline アスベスト種類 & クリソイル & クリソタイル \\
\hline 含有率 $(\mathrm{wt} \%)$ & 5.8 & \\
\hline
\end{tabular}

表 13 屋外ばくろに供した試験体の 下地調整時に発生したダスト中のアスベスト含有率

\begin{tabular}{|c|c|c|c|c|c|}
\hline No. & & ダスト中のア & ベスト & $\begin{array}{l}\text { (参考) 成形极 } \\
\text { ス卜 }\end{array}$ & 中のアス心 \\
\hline 1 & アスベスト種類 & 剖多价 & クロシドライト & 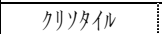 & クロシドライト \\
\hline & 含有率（wt\%） & 4.0 & 1.2 & 7.1 & 2.2 \\
\hline 2 & アスベスト種類 & クリソタ & イル & クリソタ & イル \\
\hline & 含有率 (wt\%) & & 2.3 & & 8.1 \\
\hline
\end{tabular}

下地調整後に、より良好な素地面が得られると推測される下地調整 方法のアスベスト繊維の飛散性の確認も含め、今後の課題としたい。 謝辞: 本研究の一部は環境省公害防止等試験研究費により実施され た。また、一部を独立行政法人建築研究所と日本建築仕上材工業会、 （社）日本塗装工業会及びN P O法人住宅外装テクニカルセンターと の共同研究として実施した。記して謝意を表する。

\section{参考文献}

1) 建築改修工事監理指針（平成 22 年版）、財団法人建築保全センター

2）本橋健司、林昭人、古賀純子、田村昌隆、アスベスト含有スレート板の下 地調整時におけるアスベスト繊維数濃度、日本建築学会大会学術講演梗概 集 A-1、pp. 307-308、2010 年 8 月

3) 本橋健司、林昭人、既存アスベスト含有成形板の表面劣化度判定手法、日 本建築学会大会学術講演梗概集 A-1、pp. 425-426、2008 年 9 月

4) JIS A 1481:2008（建材製品中のアスベスト含有率測定方法）

5) JIS K 3850-1:2006（空気中の緎維状粒子測定方法）

6) 水道とアスベスト、社団法人日本水道協会、平成元年 2 月 